\title{
Difficulty To Overcome Supply Chain Challenges Faced By Vehicle Manufacturers In South Africa
}

\author{
Intaher Marcus Ambe, University of South Africa (UNISA), South Africa
}

\begin{abstract}
This article explores supply chain challenges faced by light vehicle manufacturers in South Africa and determines how difficult the challenges are to overcome. A mixed research design was employed. The supply chain challenges revealed in the findings were categorised into technological, infrastructure, cost, market/service, relationship and production/skills challenges. Most are difficult to quantify, such as road freight volumes, port delays, rail unreliability, high fuel costs, high operating costs and high port charges. Nevertheless, addressing some of the challenges could help manufacturers to become more competitive, for example by replacing outdated assembly/manufacturing tools, finding new markets, preventing or reducing the effect of cancellation of customer orders and improving the level of service in general. This article provides an understanding of the challenges in the supply chain, which is paramount not only for locally manufactured vehicle supply chain practitioners, but also for the automotive industry and South Africa as a whole.
\end{abstract}

Keywords: Supply Chain Challenges; Difficult to Overcome; Automotive Industry; South Africa

\section{INTRODUCTION}

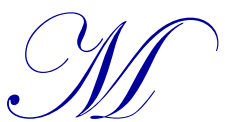

anaging a supply chain today is a fluid process. Due to increasing globalisation, there are incredible opportunities as well as increased risks. Supply chain managers face intricate and complex situations which are sometimes difficult to overcome (Updike, 2012). Supply chain management (SCM), according to Duarte and Machado (2011, p. 328), is not only a challenging concept with elusive goals, it is a critical success factor in business today. How organisations manage their supply chains, the challenges they face and the goals they set, reflects a single-minded focus on absorbing costs and increasing efficiency and effectiveness. In recent years, the automotive industry has experienced strong competition on a global scale in highly competitive markets (Pires \& Neto, 2008, p. 328). It has been challenged by strong pressures for reductions in price and delivery time, improvements to quality and overall customer service, and environmentally friendly products (Pires \& Cardoza, 2007). Limited, inflexible production and assembly capacities and long delivery lead times also contribute to high dealer inventory levels in the form of safety stock (Schwarz, 2008, p. 2). In addition, automakers and suppliers tend to build up buffer inventory, which limits their ability to react flexibly to changes in customer demand. Globally, supply chain complexity is growing and overcoming the challenges is a challenge in itself.

In South Africa, SCM is one of the important functional areas in the automotive industry and its contribution to the country's economy has been particularly noteworthy (Pires \& Neto 2008, p. 328). The sector's contribution of 7\% of South Africa's gross domestic product (GDP) was R3 251.4 billion in 2012 (AIEC, 2013, p. 7). However, the industry faces new and pressing supply chain challenges for local manufacturers and it is internationally uncompetitive (Supplychainforesight, 2010). Scholars such as Naude and Badenhorst-Weiss (2011, p. 70); Ambe and Badenhorst-Weiss (2011, p. 355); and Mphahlwa (2008, p. 2), as well as publications such as the Supply Chain Intelligence Report (2009) and the Supply Chain Foresight Report (2010), have identified some of the challenges faced by the automotive industry as: intensified competition in the global market; low levels of 
collaboration; lack of market sensitivity or reaction to the changing market; pressure from original equipment manufacturers (OEMs) to reduce prices; unreliability of rail transport; rail capacity problems; and the high cost of South African ports. However, none of these studies indicated the extent to which these challenges are felt by the vehicle manufacturers or how to overcome them.

Considering the profound importance of SCM to business success and to the South African automotive industry (Marchese \& Paramasivam, 2013), it is worth investigating the extent of what is clearly a growing threat (challenge) and how supply chain managers can best proceed to overcome it. The purpose of this article is to explore supply chain challenges faced by light vehicle manufacturers in South Africa and to determine the extent to which the challenges can be overcome. The purpose of this article is defined by the following research questions:

Research Question 1: What are the supply-chain challenges facing light vehicle manufacturers in South Africa? Research Question 2: How difficult it is to overcome supply-chain challenges faced by vehicle manufacturers in South Africa?

The findings of this article indicate challenges that could become sources of competitive advantage if vehicle manufacturers focus their time and efforts on managing them, thus contributing to the body of knowledge in SCM. The following section reviews the literature. Subsequent sections contain the research methodology, results and discussions and finally the conclusion.

\section{OVERVIEW OF SUPPLY CHAIN MANAGEMENT}

\section{Background}

Supply chain management is critical for the success of organisations, as they need to respond to increasing levels of volatility in demand (Fawcett, Magnan, \& McCarter, 2008, p. 35). SCM has gained recognition as a powerful tool that affords companies the opportunity to achieve a competitive advantage (Christopher, 2005, p. 6). According to Leenders and Fearon (2004, p. 10), "SCM is the systems approach to managing the entire flow of information, materials and services from the raw materials suppliers through factories and warehouses to the end customer." Christopher (2005, p. 5) defined SCM as "the management of upstream and downstream relationships with suppliers and customers to deliver superior customer value at less cost to the supply chain as a whole." Gansler, Luby, and Kornberg (2004, p. 8) noted that SCM is the management and control of all materials, funds, and related information in the logistics process from the acquisition of raw materials to the delivery of finished products to the end user. The ultimate goal of an SCM process is to create customer and shareholder value, and it is thus often called a value delivery system. This goal can be achieved by using technology and teamwork to build efficient and effective processes that create value for the end customer (Fawcett, Ellram, \& Ogden, 2007, p. 8).

\section{Supply Chain Practices in the Automotive Industry}

The industry is the largest manufacturing sector in the world (Nag, Banerjee, \& Chatterjee, 2007, p. 1; Kehbila, Ertel, \& Brent, 2009, p. 310) and is also one of the largest investors in research and development (OICA, 2009). Owing to the increasing number of vehicle models being introduced in segmented markets, executive managers are seeking both growth and cost reductions in order to be more competitive and profitable (IBM, 2009, p. 1). In South Africa, the automotive industry plays a significant role in the economy, and is often referred to as the barometer of the economic health of the country. The industry employs about 9 million people directly in producing vehicles and the automotive components that go into them (AIEC, 2012, p. 13). The industry sector's contribution to South Africa's GDP was R2 964 billion in 2011, or 6.8\%. Major international assemblers and manufacturers have established operations in South Africa (Alfaro, Bizuneh, Moore, Ueno, \& Wang, 2012, p. 15). The industry supply chain structure has supply and demand sides. As noted by Lamprecht (2006, p. 15), the key role players in the supply side attempt to meet the needs of the demand side in major global trends and developments governing the automotive industry. 


\section{Supply Chain Challenges in the Automotive Industry}

The automotive industry faces some tricky and demanding circumstances, so OEMs are scrambling to slash production and reduce manufacturing costs. Manufacturers are required to enhance quality, improve styling, increase organisational efficiencies and drive innovative features into their products in an effort to attract customers and expand into new markets. They continually put pressure on their tiered suppliers to reduce costs and increase output and quality (Pires \& Neto, 2008, p. 328). Studies and reports outlining supply chain issues in South Africa show a pattern: local circumstances, economic conditions, inefficiencies in supply chains, customer pressure and global competition are to blame for the tremendous pressure on the South African automotive industry.

According to Cheng, Lai, and Singh (2007), information technology is used to conduct business transactions, share information, and facilitate collaboration as the main determinants of a supply chain's effectiveness (Piderit, Flowerday, \& Von Solms, 2011). According to the CSIR (2009) report, there is high usage of technology in the South African automotive industry. However, high-use technology is challenged by low levels of collaboration (Barnes \& Morris, 2008, 34). Importing and transporting parts to assembly plants and transporting and exporting finished products are two critical steps in the assembly and export process, but managing the process is a challenge. The number of containers that can be cleared through South African ports per hour is too low, with Cape Town the most uncompetitive among 17 ports included in a study conducted by the Automotive Industry Development Centre (Van der Merwe, 2009). According to the Auto World (2010) report, infrastructure bottlenecks are causing substantial inefficiency in the motor industry pipeline and need to be addressed by the industry as a whole. There are congested ports and terminals, particularly in Durban, and insufficient "car-train" capacity, especially between Durban and Gauteng (Van der Merwe, 2009).

Cost is also a major challenge in the South African automotive industry (Naude \& Badenhorst-Weiss, 2011, p. 94). The South African Port Authority charges $\$ 821,6$ to move one 40 -foot container, in comparison with Argentina at $\$ 470$, Brazil at $\$ 364$, and China at $\$ 80$ (Van der Merwe, 2009). Walker (2006) asserted that new vehicles are still expensive in South Africa in relative terms. According to Walker (2006), an average South African household would need 164 weeks of earnings to buy and finance an average-priced new car, compared to just 26 weeks in the US, according to the McCarthy Affordability Index. Naude and Badenhorst-Weiss (2011, p. 71) reported that on average, South Africa was $20 \%$ more expensive as a vehicle manufacturing base than Western Europe, while China was 12\% less expensive than Western Europe. South Africa is therefore $30 \%$ to $40 \%$ more expensive than China. Smit (2010) asserted that transport remains the main contributor to logistics costs and is thus one of the greatest challenges to the automotive industry. The freight system is heavily weighted towards road freight. While this means a better, more reliable and more direct service, it also causes heavy road use, congestion, cost escalation and infrastructural damage, and hence high transportation costs. According to Smit (2010), transportation costs amount to 54\% of logistical costs, $14 \%$ higher than the world average. In Asia manufacturers have managed to reduce costs dramatically, which raises concern about the continued viability of South Africa's automotive sector (Piderit et al., 2011).

Improving firm-level competitiveness and quality is a challenge (Barnes \& Morris, 2008, p. 47). The key policy question, not only for South Africa but also for other developing countries, is how to become more competitive. Auto World (2010) reported that the automotive industry in South Africa, is unfortunately not renowned for world-class service. OEMs are placing production facilities in countries mainly to tap into their huge domestic markets (Alfaro et al., 2012, p. 9). Given economies of scale in the automotive industry, South Africa's domestic market, while significant, is not large enough for production to be economically viable without significant exports to outside markets. Indeed, South Africa exports a far greater proportion of its automobile production than China, India, or Brazil (Alfaro et al., 2012, p. 9). South Africa's true competitors are other medium-sized emerging market economies like Mexico, Egypt, and Thailand.

In South Africa, the Broad-Based Black Economic Empowerment (BBBEE) Act 53 of 2003 was promulgated to ensure that procurement in the public and private sectors supports the economic empowerment of previously politically disadvantaged individuals through its suppliers. Government has mandated various business sectors to collaborate in developing their own sector-specific charters that outline the sector's plans for transformation and the implementation of the BBBEE Act (Pillay \& Phillips, 2009, p. 30). One of the measures in 
the Act has particular implications for relationships in supply chain management. The Act requires that organisations (including OEMs) must target and purchase their supplies from previously disadvantaged organisations and use their economic power to force their suppliers to buy from previously disadvantaged suppliers. It also requires active engagement in transforming organisations to include black individuals at all levels. The government uses a "balanced scorecard" to determine progress made by businesses and sectors in achieving BBBEE (Republic of South Africa, 2003). However, it has been difficult to comply and meet BBBEE targets (Alfaro et al., 2012, p. 24).

The South African government, realising the weak competitive position of the South African automotive industry, has put pressure on OEMs to improve their local content to $70 \%$ (through the Automotive Production and Development Programme), in order to negate the costs of importing components using long supply chains and weathering a fluctuating currency (Mphahlwa, 2008, p. 2). Barnes and Morris (2008, p. 34) asserted that despite being massive-scale manufacturers, General Motors, Ford, Volkswagen, and DaimlerChrysler have shown poor financial performance, largely because of consistently high production overcapacity (between $25 \%$ to $30 \%$ ) over the last ten years. Poor availability of skills is an impediment to supply chain practices in South Africa. Skills shortages are a major constraint on research and development, particularly the national shortage of qualified engineers.

The focus of this article is particularly on supply chains of locally manufactured vehicle models, and not on the industry as a whole or on certain role players in the industry.

\section{RESEARCH METHODOLOGY}

To find an answer to the research objectives, an exploratory and descriptive qualitative research design comprising two phases was employed. The first consisted of interview-based purposive sampling techniques used with supply chain managers, which were intended to provide in-depth understanding of the challenges facing the industry. The interviews were analysed descriptively using content analysis. The literature review and the interviews provided inputs for identifying supply chain challenges. Six interviews were conducted among three light vehicle manufacturers.

In the second phase of the research, the challenges identified were then empirically validated to determine the extent to which they could be overcome, as set out below:

- $\quad$ Research strategy: The research strategy was a survey, a form of research in which the researcher interacts with respondents to obtain facts, opinions and attitudes (McDaniel \& Gates, 2001, p. 30). In survey research, a sample population is interviewed in some form or the behaviour of respondents is observed and described in some way (Zikmund, Babin, Carr, \& Griffin, 2010, p. 67).

- $\quad$ Population and sample: The target population was the OEMs in the South African automotive industry (local manufacturers). In this study, the total target population was used (all light vehicle manufacturers in South Africa, except one that did not participate). A purposive sampling technique was used to determine the respondents. The intention of using purposive sampling was to focus on those who have expert knowledge about supply chain practices and operations in the automotive industry (senior supply chain managers). Specific participants for interviews were thus selected according to their strategic positions in the supply chain.

- Data collection methods: Both primary and secondary sources of information were used. Primary data sources were collected through face-to-face interviews (empirical study), while secondary data sources were collected through extensive literature reviews (literature study). The interview questions were semistructured and were measured using a five-point Likert response scale to determine the difficulty of overcoming the challenges, with the end points as follows:

1. very easy to fix, few resources needed, little time or complexity;

2. somewhat easy to fix, some resources and time needed, but not taxing to the enterprise;

3. moderately difficult, can be remedied with moderate resources and time, moderate complexity;

4. somewhat difficult to fix, requires resources, time and is most likely complex; and

5. extremely difficult to fix, high impact on resources and time, very complex. 
A total of $24(\mathrm{~N}=24)$ in-depth interviews were conducted with six different manufacturers.

- Data analysis: After the data collection process, data was organised and analysed. The data for this study was analysed descriptively using the Statistical Package for Social Sciences (SPSS). The results are presented using mean and median scores.

\section{RESULTS AND DISCUSSION} objectives:

This section of the article presents the results and discussions of the finding in relation to the research

Research Question 1: What are the supply-chain challenges facing light vehicle manufacturers in South Africa?

Analysis of the interviews resulted in 23 statements representing potential challenges. These challenges were categorised into six major categories: technological challenges, infrastructural challenges, cost challenges, market/service challenges, relationship challenges, and skills challenges. The validation of the variables (\% of agreement) is indicated in Table 2 . Table 1 summarises the supply chain challenges facing the automotive industry and gives a description of the categories.

Table 1: Supply Chain Challenges in the South African Automotive Industry

\begin{tabular}{|c|c|}
\hline Category of Challenge & Description \\
\hline \multirow{3}{*}{ Technological challenges } & Inadequate information systems \\
\hline & Inefficient planning and forecasting tool \\
\hline & High cost of replacing obsolete assembly/manufacturing tools \\
\hline \multirow{5}{*}{ Infrastructural challenges } & Unsustainable infrastructure \\
\hline & Unreliable rail transport \\
\hline & Problems with rail capacity \\
\hline & Increased road freight volumes \\
\hline & Delays at ports \\
\hline \multirow{4}{*}{ Cost challenges } & High fuel costs \\
\hline & High operating costs \\
\hline & High costs at South African ports \\
\hline & High prices of materials/components resulting in high operating costs \\
\hline \multirow{3}{*}{ Market/service challenges } & Difficulty finding new markets \\
\hline & Customers sometimes cancel their orders \\
\hline & Difficulty in improving service levels \\
\hline \multirow{4}{*}{ Relationships challenges } & Difficulty in verifying BEE status (scorecards) of strategic suppliers \\
\hline & Difficulty in collaborating with strategic suppliers \\
\hline & Difficulty in collaborating with strategic customers \\
\hline & Operating with a low level of collaboration \\
\hline \multirow{4}{*}{ Skills challenges } & Unreliable production schedules \\
\hline & Lack of capacity \\
\hline & Lack of skills \\
\hline & Labour problems \\
\hline
\end{tabular}

Research Question 2: $\quad$ How difficult it is to overcome supply chain challenges faced by vehicle manufacturers in South Africa?

In order to determine the difficulty of overcoming the challenges, an empirical study was conducted. Table 2 presents the frequency distribution (\%) per statement in each category on the level of agreement on supply chain challenges and the difficulty of overcoming them. 
Table 2: Difficulty of Overcoming Challenges

\begin{tabular}{|c|c|c|c|c|c|c|}
\hline \multirow{2}{*}{ Challenges } & \multirow{2}{*}{$\begin{array}{l}\text { Agreed } \\
(\%)\end{array}$} & \multicolumn{5}{|c|}{ Difficulty of overcoming (\%) } \\
\hline & & $\mathbf{E}$ & SE & M & SD & ED $^{1}$ \\
\hline \multicolumn{7}{|l|}{ Technological challenges } \\
\hline Inadequate information systems & 25.0 & 0.0 & 8.3 & 0.0 & 0.0 & 16.7 \\
\hline Inefficient planning and forecasting tools & 25.0 & 0.0 & 8.3 & 0.0 & 0.0 & 16.7 \\
\hline $\begin{array}{l}\text { Costly to replace obsolete assembly/manufacturing } \\
\text { tools }\end{array}$ & 83.3 & 0.0 & 0.0 & 0.0 & 75.0 & 8.3 \\
\hline \multicolumn{7}{|l|}{ Infrastructural challenges } \\
\hline Unsustainable infrastructure & 25.0 & 0.0 & 0.0 & 0.0 & 25.0 & 0.0 \\
\hline Unreliable rail transport & 50.0 & 0.0 & 0.0 & 0.0 & 33.3 & 16.7 \\
\hline Increased road freight volumes & 66.7 & 0.0 & 16.7 & 16.7 & 25.0 & 8.3 \\
\hline Delays at ports & 91.7 & 0.0 & 8.3 & 0.0 & 25.0 & 58.3 \\
\hline \multicolumn{7}{|l|}{ Cost challenges } \\
\hline High fuel costs affect operating costs & 100.0 & 0.0 & 0.0 & 8.3 & 25.0 & 66.7 \\
\hline High operating costs & 75.0 & 0.0 & 0.0 & 8.3 & 58.3 & 8.3 \\
\hline High costs incurred at South African ports & 91.7 & 0.0 & 0.0 & 16.7 & 25.0 & 50.0 \\
\hline High prices of materials/components & 66.7 & 0.0 & 0.0 & 16.7 & 33.3 & 16.7 \\
\hline \multicolumn{7}{|l|}{ Market/service challenges } \\
\hline Difficulty finding new markets & 58.3 & 0.0 & 0.0 & 0.0 & 33.3 & 25.0 \\
\hline Customers sometimes cancel their orders & 75.0 & 0.0 & 8.3 & 16.7 & 41.7 & 8.3 \\
\hline Improving our service level & 66.7 & 0.0 & 8.3 & 33.3 & 25.0 & 0.0 \\
\hline \multicolumn{7}{|l|}{ Relationship challenges } \\
\hline $\begin{array}{l}\text { Difficult to verify the BEE status (scorecards) of our } \\
\text { strategic suppliers }\end{array}$ & 8.3 & 0.0 & 0.0 & 8.3 & 0.0 & 0.0 \\
\hline $\begin{array}{l}\text { Sometimes it is difficult to collaborate with our } \\
\text { strategic suppliers }\end{array}$ & 25.0 & 0.0 & 16.7 & 8.3 & 0.0 & 0.0 \\
\hline $\begin{array}{l}\text { Sometimes it is difficult to collaborate with our } \\
\text { strategic customers }\end{array}$ & 16.7 & 0.0 & 8.3 & 8.3 & 0.0 & 0.0 \\
\hline \multicolumn{7}{|l|}{ Production/skills challenges } \\
\hline Unreliable production schedules & 8.3 & 0.0 & 0.0 & 0.0 & 0.0 & 8.3 \\
\hline Lack of capacity & 41.7 & 0.0 & 0.0 & 8.3 & 8.3 & 25.0 \\
\hline Lack of skills & 58.3 & 0.0 & 0.0 & 0.0 & 33.3 & 25.0 \\
\hline Labour problems & 66.7 & 0.0 & 0.0 & 8.3 & 41.7 & 8.3 \\
\hline
\end{tabular}

\section{Difficulty of Overcoming Technological Challenges ${ }^{2}$}

(1) All of the $83.3 \%$ of respondents who said they incurred high costs when replacing obsolete assembly/manufacturing tools indicated that the problem was difficult to overcome. Three-quarters $(75 \%)$ were of the opinion that this challenge was somewhat difficult to overcome and $8.3 \%$ thought that it was extremely difficult to overcome. This shows that replacing obsolete assembly/manufacturing tools was the most difficult technological challenge to overcome.

\section{Difficulty of Overcoming Infrastructural Challenges}

(1) Regarding the challenge of unreliable rail transportation, $33.3 \%$ of the $50.0 \%$ of respondents who indicated that this was a problem said it was somewhat difficult to resolve, while $16.7 \%$ indicated that it was extremely difficult to sort out.

(2) Of the almost $66.7 \%$ of respondents who regarded "road freight volumes" as a problem, $16.7 \%$ said it was somewhat easy to resolve; $16.7 \%$ indicated that it was moderately difficult to sort out; $25 \%$ indicated that it was somewhat difficult to overcome and $8.3 \%$ responded that it was extremely difficult to sort out.

\footnotetext{
${ }^{1}$ For the purpose of analysis, the following abbreviations were used: E for very easy to overcome; SE for somewhat easy to overcome; M for moderate to difficult to overcome; SD for somewhat difficult to overcome; and ED for extremely difficult to overcome.

${ }^{2} \mathrm{NB}$ : Only the challenges that were difficult to overcome are discussed in this section; one respondent who agreed that labour problems were a challenge, did not indicate the complexity of overcoming the challenge.
} 
(3) Almost all the respondents (above 90\%) regarded "port delays" as a problem. Of the respondents, $8.3 \%$ said it was easy to resolve; $25 \%$ that it was somewhat difficult to overcome; and over half (58.3\%) said it was extremely difficult to sort out.

Port delays, increases in road freight volume and unreliable rail were all mentioned as difficult challenges to overcome that were not within the control of automotive manufacturers.

\section{Difficulty of Overcoming Cost Challenges}

(1) All the respondents (100\%) indicated that "high fuel costs" affect their operating costs. Only $8.3 \%$ of the respondents indicated that the problem was moderately difficult to resolve; a quarter (25\%) said it was somewhat difficult to resolve, and the majority (66.7\%) suggested that it was extremely difficult to overcome.

(2) Of the respondents, $75.0 \%$ regarded "high operating costs" as a problem. A total of $8.3 \%$ indicated that it was moderately difficult to overcome this problem; more than half $(58.4 \%)$ said that it was somewhat difficult to resolve and only $8.3 \%$ indicated that it was extremely difficult to sort out.

(3) The majority (91.7\%) of the respondents indicated that "incurring high costs at South African ports" was a problem. A total of $16.7 \%$ asserted that it was moderately difficult to sort out the problem; $25 \%$ said that it was somewhat difficult to resolve and half (50\%) indicated it was extremely difficult to overcome.

(4) Two-thirds $(66.7 \%)$ of the respondents indicated that "prices of materials and components are high." A total of $16.7 \%$ said that this problem was moderately difficult to solve; $33.3 \%$ indicated that it was somewhat difficult to overcome and $16.7 \%$ stated it was extremely difficult to sort out.

Overall, since cost challenges are beyond the control of automotive manufacturers, vehicle manufacturers should concentrate on higher productivity and efficiency in the supply chain to make up for this.

\section{Difficulty of Overcoming Market/Service Challenges}

(1) For 58.3\% of the respondents, "finding new markets" is a challenge. A third (33.3\%) of the respondents indicated that the problem was somewhat difficult to overcome, and a quarter (25\%) indicated that it was extremely difficult to resolve.

(2) For $75.0 \%$ of the respondents, "customers sometimes cancel their orders" posed a challenge. Only $8.3 \%$ of the respondents noted that it was somewhat easy to resolve the problem; $16.7 \%$ said that it was moderately difficult; $41.7 \%$ rated it as somewhat difficult to overcome, and $8.3 \%$ felt that it was extremely difficult to sort out.

(3) Two-thirds (66.7\%) of the respondents indicated that "improving service levels" was a challenge. Only $8.3 \%$ held that the problem was somewhat easy to solve; a third (33.3\%) said that it was moderately difficult to sort out and $25 \%$ indicated that it was somewhat difficult to overcome.

The results show that automotive manufacturers do seem to have some control over the cancellation of orders and service levels. These challenges should, therefore, be the focus of manufacturers' efforts to become more competitive.

\section{Difficulty of Overcoming Relationship Challenges} discussion.

Since none of the relationship-related issues were regarded as challenging, this issue does not justify further

\section{Difficulty of Overcoming Production/Skills Challenges}

(1) A total of $58.3 \%$ of the respondents regarded "lack of skills" as a challenge. A third (33.3\%) of them indicated that the problem was somewhat difficult to resolve, while a quarter (25\%) said that it was extremely difficult to overcome. 
(2) Again, $66.7 \%$ of the respondents indicated that "labour issues" posed a challenge. Only $8.3 \%$ indicated that it was moderately difficult to resolve this problem; more than a third (41.7\%) indicated that it was somewhat difficult to overcome and $8.3 \%$ indicated that it was extremely difficult to sort out.

This result shows that both labour issues and lack of skills appear to be difficult challenges to overcome. Skills development can only be fixed over the long term, which puts it somewhat more within the control of manufacturers than labour problems. The results in Table 2 show that some of the challenges in the South African automotive industry are complex and difficult to overcome. Regarding technological challenges, it is extremely difficult to reduce the high costs incurred when replacing obsolete manufacturing tools. Infrastructural challenges (road freight volumes and port delays) are also extremely difficult to overcome. Manufacturers have little or no control over these challenges because the government (Transnet) is in charge of infrastructure development. The majority of the respondents indicated that cost challenges (high fuel costs, high operating costs, high costs incurred at ports and high prices of materials) were somewhat difficult and sometimes extremely difficult to fix. This is understandable because the manufacturers are not the primary determinants of price; the government and the competitive position of the economy impact on cost dynamics in this case.

The respondents also rated the problem of finding new markets as "somewhat" and "extremely" difficult to resolve. These decisions are dependent on the competitive position of the local industry compared with international automotive manufacturers, as well as the role of parent companies. Owing to the impact of the emerging economies, it is also difficult for South African automotive manufacturers to explore new markets abroad. Hence, it is suggested that the industry should endeavour to build a competitive advantage in African markets. Furthermore, most of the respondents who agreed that customers sometimes cancelled their orders stated that this is a difficult challenge to overcome. Globalisation is the cause, because nowadays customers are spoilt for choice.

Skills shortages were identified as a major challenge that is somewhat or extremely difficult to fix. This is a national dilemma in South Africa and cannot be resolved in the short term by individual manufacturers. Labour issues were also acknowledged as difficult to sort out, owing to the politicisation of the labour market and strict labour laws. Table 3 summarises the challenges facing the South African automotive supply chain (information is only given where there was more than $50 \%$ agreement that it is a challenge). Because most of the important challenges are to a great extent outside the control of individual manufacturers or the industry as a whole, they are thus difficult to meet.

Table 3: Supply Chain Challenges That are Difficult to Overcome

\begin{tabular}{|l|c|c|}
\hline \multicolumn{1}{|c|}{ Challenges } & \% of agreement & \% difficulty of overcoming challenge \\
\hline Technological Challenges & & 83.3 \\
\hline Costly to replace obsolete assembly/manufacturing tools & 83.3 & 50 \\
\hline Infrastructural Challenges & & 83.4 \\
\hline Increased road freight volumes & 66.7 & 100.0 \\
\hline Port delays & 91.7 & 75.0 \\
\hline Cost Challenges & & 91.7 \\
\hline High fuel costs affecting operating costs & 100.0 & 66.7 \\
\hline High operating costs & 75.0 & \\
\hline High costs at South African ports & 91.7 & 58.4 \\
\hline High prices of materials/components & 66.7 & 66.7 \\
\hline Market/Service Challenges & & \\
\hline Difficult to find new markets & 58.4 & 58.3 \\
\hline Customers sometimes cancel their orders & 75.0 & \\
\hline Improving our service levels & 66.7 & \\
\hline Production/Skills Challenges & & \\
\hline Lack of skills & 58.3 & 58.3 \\
\hline Labour problems & 66.7 & 50.0 \\
\hline
\end{tabular}

Vehicle manufacturers should first focus on challenges that are easy to overcome, because they require less effort. Most of the main problems mentioned in Table 4 (road freight volumes, delays at port, unreliability of rail, high fuel costs, high operating costs, high costs at ports, and high prices of materials) are difficult to resolve and 
beyond the control of manufacturers. However, a few of the challenges that are difficult to overcome are actually opportunities for manufacturers to focus their efforts to become more competitive, such as by replacing outdated assembly/manufacturing tools and finding new markets. Cancellation of customer orders is relatively easy to overcome and improving service levels could be a starting point for improvement.

In summary, the radar graph in Figure 1 indicates the percentage of respondents who agreed that the statement was a challenge (blue line) and the "difficult to overcome" category chosen by the majority of respondents who agreed that it was indeed a challenge (red line).

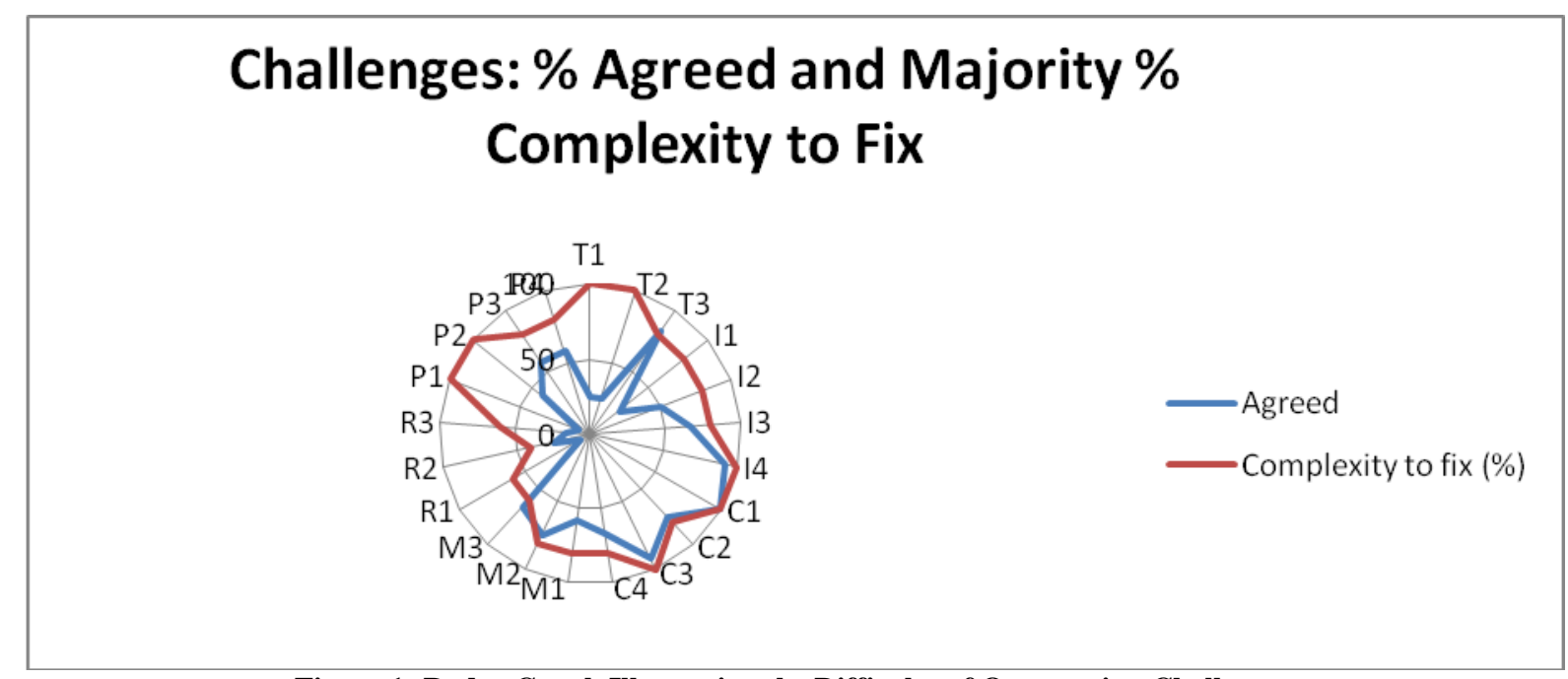

Figure 1: Radar Graph Illustrating the Difficulty of Overcoming Challenges

In Figure 1, the closer the blue line is to the centre, the less challenging the issue is, and the closer the red line is to the centre, the easier it is to resolve the problem. The radar graph clearly illustrates that the problems/challenges manufacturers encounter are difficult to extremely difficult to overcome and not really within their control.

Table 4 gives a description of the challenges illustrated in Figure 1.

Table 4: Description of the Radar Graph

\begin{tabular}{|l|l|}
\hline \multicolumn{1}{|c|}{ Challenge } & \multicolumn{1}{c|}{ Description of Challenge } \\
\hline Technological Challenges \\
\hline T1 & We have inadequate information systems. \\
\hline T2 & We do not have an efficient planning and forecasting tool. \\
\hline T3 & We incur high costs when replacing obsolete assembly/manufacturing tools. \\
\hline Infrastructural Challenges \\
\hline I1 & We do not have sustainable infrastructure. \\
\hline I2 & Rail transport is unreliable. \\
\hline I3 & There is increased road freight volume. \\
\hline I4 & We are challenged by delays at ports. \\
\hline Cost Challenges & \\
\hline C1 & High fuel costs affect our operating costs. \\
\hline C2 & We have high operating costs. \\
\hline C3 & We incur high costs at South African ports. \\
\hline C4 & The prices of materials/components are high. \\
\hline Market/Service Challenges \\
\hline M1 & It is difficult to find new markets. \\
\hline M2 & Our customers sometimes cancel their orders. \\
\hline M3 & We are challenged to improve our service levels. \\
\hline
\end{tabular}


Table 4 cont.

\begin{tabular}{|l|l|}
\hline \multicolumn{2}{|l|}{ Relationships Challenges } \\
\hline R1 & It is difficult to verify the BEE status (scorecards) of our strategic suppliers. \\
\hline R2 & It is sometimes difficult to collaborate with our strategic suppliers. \\
\hline R3 & It is sometimes difficult to collaborate with our strategic customers. \\
\hline Production/Skills Challenges \\
\hline P1 & We have unreliable production schedules. \\
\hline P2 & We are challenged by a lack of capacity. \\
\hline P3 & We are challenged by lack of skills. \\
\hline P4 & We are challenged by labour problems. \\
\hline
\end{tabular}

\section{CONCLUSION}

This article indicates that the cost of replacing existing assembly/manufacturing tools is a great challenge for manufacturers. Cost challenges (which include high fuel costs, operating costs, costs due to delays at ports, and high prices of components and materials) affect the performance of the industry and its competitive position worldwide. This challenge obviously leads to high prices for new vehicles in South Africa, stops South Africa's automotive manufacturers being globally competitive and therefore influences automobile exports. Capacity, skills, and labour issues were also identified as challenges impacting the performance of local automotive manufacturers in South Africa.

The results also revealed that all the respondents who agreed on a challenge (more than 50\% agreement) also agreed that the challenge was difficult to overcome; the exception is the challenge to improve service levels, where $66.7 \%$ of the respondents agreed that it was not difficult to overcome and only $25 \%$ of the respondents disagreed. Exactly $33.3 \%$ of the respondents were unsure about the difficulty of meeting the challenge. Therefore, vehicle manufacturers should first give attention to those challenges that are easy to overcome (inadequate information systems; inefficient planning and forecasting; unsustainable infrastructure; verifying BBBEE status of strategic suppliers; and collaboration with strategic suppliers), because they require less effort. As indicated by the degree of difficulty involved in overcoming them, these challenges inhibit supply chain best practices.

Most of the difficult challenges, such as road freight volumes, port delays, unreliability of rail transport, high fuel costs, high operating costs, high port charges, and high prices of materials are actually beyond the control of the manufacturers. A few of the challenges could provide opportunities for the manufacturers to focus their efforts to become more competitive, such as replacing outdated assembly/manufacturing tools; finding new markets; dealing with the cancellation of customer orders; and improving service levels.

\section{AUTHOR INFORMATION}

Intaher Marcus Ambe, University of South Africa (UNISA), Department of Business Management, South Africa. E-mail: Ambeim@unisa.ac.za

\section{REFERENCES}

1. AIEC (Automotive Industry Export Council). (2012). Automotive export manual. NAAMSA: Pretoria, South Africa.

2. Alfaro, A. L., Bizuneh, G., Moore, R., Ueno, S., \& Wang, R. (2012). South Africa: Automotive cluster, microeconomics of competitiveness. Harvard Business School: 1260, Kennedy School of Government: PED-329.

3. Ambe, I. M., \& Badenhorst-Weiss, J. A. (2011). South African automotive industry: Trends and challenges in the supply chain. Journal of Contemporary Management, 8, 337-362.

4. $\quad$ Auto World. (2010). Motor industry needs to address challenges. Retrieved from http://www.autoworld.co.za/newsarticle.aspx?article=3706

5. Barnes, J., \& Morris, M. (2008). Staying alive in the global automotive industry: What can developing economies learn from South Africa about linking into global automotive value chains? European Journal of Development Research, 20(1), 31-55. 
6. Cheng, T. C. E., Lai, K.-H., \& Singh, N. (2007). Intra-organizational perspectives on IT-enabled supply chains. Communications of the ACM, 50(1), 59-65.

7. Christopher, M. (2005). Logistics and supply chain management: Creating value-adding networks (3rd ed.). Harlow, England: Prentice Hall.

8. Duarte, S., \& Machado, V.C. (2011). Manufacturing paradigms in supply chain management. International Journal of Management Science and Engineering, 6(5), 328-342.

9. $\quad$ Fawcett, S. E., Ellram, L. M., \& Ogden, J. A. (2007). Supply chain management: From vision to implementation. Upper Saddle River, NJ: Prentice Hall.

10. Fawcett, S. E., Magnan, G. M., \& McCarter, M. W. (2008). Benefits, barriers and bridges to effective supply chain management. Supply Chain Management: An International Journal, 13(1), 35-48.

11. Gansler, C., Luby, R. E. Jr., \& Kornberg, B. (2004). Supply chain management in government and business. In J. Gansler \& J. R. Luby (Eds), Transforming government. MD, USA: IBM Centre for the Business for Government Series.

12. IBM. (2009). The smarter supply chain of the future. Automotive industry edition. New York: IBM.

13. Kamal, Y., \& Ferdousi, M. (2009). Supply chain management practices in automobile industry: Study of Ford vs. Toyota. Dhaka University Journal of Business Studies, 30(2), 75-90.

14. Kehbila, A. G., Ertel, J., \& Brent, A. C. (2009). Strategic corporate environmental management within the South African automotive industry: motivations, benefits, hurdles. Corporate Social Responsibility and Environmental Management, 16(6), 310-323.

15. Leenders, M. R., \& Fearon, H. E. (2004). Purchasing and supply chain management (11th ed.). Chicago: Irwin.

16. Marchese, K., \& Paramasivam, S. (2013). The ripple effect: How manufacturing and retail executives view the growing challenges of supply chain risk. Retrieved from http://www.deloitte.com/us

17. McDaniel, C., \& Gates, R. (2001). Marketing research essentials. Cincinnati, OH: South-Western College.

18. Mphahlwa, M. P. (2008). Automotive development programme announcement. Retrieved from http://www.dti.gov/za/articleview.asp

19. Nag, B., Banerjee, S., \& Chatterjee, R. (2007). Changing features of the automobile industry in Asia: Comparison of production, trade and market structure in selected countries. Asia-Pacific Research and training network on Trade. (Working paper series, No.37). July 2007.

20. Naude, M. J., \& Badenhorst-Weiss, J. A. (2011). Supply chain management problems at South African automotive component manufacturers. South African Business Review, 15(1), 70-99.

21. OICA (Organisation Internationale des Constructuers d'Automobiles). (2009). Retrieved from http://www.oica.net

22. Piderit, R., Flowerday, S., \& Von Solms, R. (2011). Enabling information sharing by establishing trust in supply chains: A case study in the South African automotive industry. South African Journal of Information Management, 13(1).

23. Pillay, V., \& Phillips, S. (2009). Overview of the policy and institutional landscape for enterprise development and preferential procurement in South Africa. (Unpublished research report). Cape Town: Human Sciences Research Council.

24. Pires, S., \& Cardoza, G. (2007). A study of new supply chain management practices in the Brazilian and Spanish auto industries. International Journal of Automotive Technology and Management, 7(1), 72-87.

25. Pires, R. I. S., \& Neto, M. S. ((2008). New configurations in supply chains: The case of a condominium in Brazil's automotive industry. Supply Chain Management: An International Journal, 13(4), 328-334.

26. Schwarz, M. (2008). Trends in the automotive industry implications on supply chain management. Cisco Internet Business Solutions Group. White paper.

27. Smit, P. (2010). Industry takes strain from increasing internal logistics costs. Retrieved from http://www.engineeringnews.co.za/article/internal-costs-can-strain-sas-logistics-indus

28. Supply Chain Intelligence Report (CSIR). (2009). Auto industry crisis - part own making. Retrieved from http://www.bizcommunity.com/Article/196/168/38180.html

29. Supplychainforesight (2010). Survey conceptualised and initiated by Barloworld Logistics, South Africa. Retrieved from http://www.supplychainforesight.co.za

30. Updike, K. (2012). Supply chain constraints present a three-part challenge to automotive suppliers. Retrieved from http://www.industryweek.com/supply-chain/supply-chain-constraints-present-three-partchallenge-automotive-suppliers 
31. Van der Merwe, J. P. (2009). The state of the automotive sector in South Africa. Trade Invest. Retrieved from http://www.tradeinvestsa.co.za/feature_articles/344969.htm

32. Walker, A. (2006). Motor industry needs to address challenges. Retrieved from http://www.carshop.co.za/NewsArticle.aspx? Article=3706

33. Zikmund, W. G., Babin, B. J., Carr, J. C., \& Griffin, M. (2010). Business research methods. Ohio: SouthWestern Cengage Learning. 